Vol 5. No 1. Februari 2021

ISSN 2580-5029

\title{
Pengaruh Pemberian Calcitriol terhadap Kadar Limfosit pada Tikus Putih (Rattus norvegicus) Galur Wistar Jantan yang Dipapar Asap Rokok
}

\author{
Jordy Oktobiannobel ${ }^{1}$, Hetti Rusmini' ${ }^{1}$, Retno Ariza Soeprihatini Soemarwotoํㄹ ${ }^{2}$ Syafa'atun \\ Malihah $^{3}$
}

\author{
${ }^{1}$ Departemen Farmakologi, Fakultas kedokteran Universitas Malahayati, Lampung, Indonesia \\ 2 Departemen Pulmonologi dan Ilmu Kedokteran Respirasi, Fakultas Kedokteran Universitas Malahayati, \\ lampung, Indonesia \\ ${ }^{3}$ Program Studi Kedokteran Fakultas Kedokteran Universitas Malahayati, lampung, Indonesia \\ Email korespondensi penulis: hettirusmini@gmail.com
}

\begin{abstract}
The health impact for active and passive smokers is damage to the organs and respiratory tract. The body organs initially experience inflammation which increases the number of white blood cells, one of which is an increase in lymphocytes. One of the efforts to reduce the damage caused free radical by cigarette smoke is by consuming Calcitriol. Objective: To determine the effect of presenting Calcitriol on lymphocyte levels in male Wistar rats (Rattus norvegicus) exposed to cigarette smoke. Methods: This type of research is a pure experimental (true-experiment) using a pre and post-test research design with a control group design to check lymphocyte levels in male Wistar rats (Rattus norvegicus). 24 rats were divided into 6 groups simultaneously. Random, namely the control group 1 (exposed to cigarette smoke and not given Calcitriol), group 2 (exposed to cigarette smoke and not given Calcitriol), placebo control group (exposed to cigarette smoke and given olive oil), treatment 1 (exposed to cigarette smoke and given Calcitriol with a dose of $0.25 \mu \mathrm{gr} / \mathrm{head}$ ), treatment 2 (exposed to cigarette smoke and given Calcitriol at a dose of $0.5 \mu \mathrm{gr}$ / head) and treatment 3 (exposed to cigarette smoke and given Calcitriol at a dose of $1 \mu \mathrm{gr} /$ head). Results: Paired t-test lymphocyte levels showed evidence that stated ( $p<0.05)$ in the K2 group ( $p=0.014)$, the K3 group ( $p=0.049)$, the P1 group ( $p=0.012)$ and the P3 group (0.001) . Meanwhile, group K1 ( $p=0.115)$ and group P2 ( $p=0.066)$ had no statistical difference. Conclusion: Calcitriol administration can reduce lymphocyte levels in male Wistar rats exposed to cigarette smoke.
\end{abstract}

Keywords: cigarette smoke, Lymphocytes, Calcitriol

\begin{abstract}
ABSTRAK
Dampak kesehatan bagi perokok aktif maupun pasif adalah terjadinya kerusakan pada organ dan saluran pernapasan. Organ tubuh porokok awalnya mengalami inflamasi yang mengakibatkan peningkatan jumlah sel darah putih, salah satunya yaitu peningkatan limfosit. Salah satu upaya untuk mengurangi resiko kerusakan sel akibat radikal bebas dari asap rokok ialah dengan mengkonsumsi Calcitriol. Tujuan: Mengetahui pengaruh pemberian Calcitriol terhadap kadar limfosit pada tikus (Rattus norvegicus) galur Wistar jantan yang dipapar asap rokok. Metode: Jenis penelitian yang digunakan adalah eksperimental murni (true-experiment) dengan menggunakan rancangan penelitian pre and posttest with control group design untuk pemeriksaan kadar limfosit pada tikus (Rattus norvegicus) galur Wistar jantan. Tikus sebanyak 24 ekor dibagi dalam 6 kelompok secara random, yaitu kelompok kontrol 1 (tidak terpapar asap rokok dan tidak diberi Calcitriol), kelompok kontrol 2 (dipapar asap rokok dan tidak diberi
\end{abstract}


Calcitriol), kelompok kontrol placebo (dipapar asap rokok dan diberi minyak zaitun), perlakuan 1(dipapar asap rokok dan diberi Calcitriol dengan dosis $0,25 \mu \mathrm{gr}$ / ekor), perlakuan 2 (dipapar asap rokok dan diberi Calcitriol dengan dosis 0,5 $\mu \mathrm{gr} /$ ekor) dan perlakuan 3 (dipapar asap rokok dan diberi Calcitriol dengan dosis 1 ugr/ ekor). Hasil: Uji Paired t-test kadar limfosit menunjukkan perbedaan yang bermakna $(\mathrm{p}<0,05)$ pada kelompok K2 $(\mathrm{p}=0,014)$, kelompok K3 $(p=0,049)$, kelompok P1 $(p=0,012)$ dan kelompok P3 $(0,001)$. Sedangkan kelompok K1 $(p=$ $0,115)$ dan kelompok P2 ( $\mathrm{p}=0,066)$ tidak terdapat perbedaan secara statistic. Kesimpulan: Pemberian Calcitriol dapat menurunkan kadar limfosit pada tikus galur Wistar jantan yang dipapar asap rokok.

Kata Kunci: panduan penulis, abstrak, template artikel

\section{PENDAHULUAN}

Indonesia merupakan negara ketiga yang memiliki jumlah perokok aktif terbanyak di dunia yaitu 61,4 juta perokok setelah India dan Cina. Perilaku merokok penduduk Indonesia cenderung meningkat dari 34,2\% pada tahun 2007 menjadi 36,3\% (WHO, 2015). Prevalensi perokok pasif di Indonesia lebih banyak dibandingkan dengan perokok aktif. Jumlah perokok aktif di Indonesia sebesar $34,5 \%$ sedangkan jumlah perokok pasif dikategorikan berdasarkan tempat terpaparnya, yakni didalam rumah sebesar 78,4\% dan di kantor sebesar 51,3\% (Balitbangkes RI, 2012). Menurut data Riskesdas tahun 2010, Lampung berada pada urutan ke-10 perokok terbanyak dari 33 provinsi yang berada di Indonesia dimana persentase pada perokok mencapai 38\%, posisi ini menunjukan posisi rerata perokok Indonesia yaitu 34,7\% (Kemenkes RI, 2010).

Merokok merupakan salah satu faktor risiko timbulnya berbagai penyakit jantung, inflamasi, stroke, kelainan pembekuan darah dan berbagai penyakit pernafasan. Merokok juga dapat mempengaruhi komponen darah lain seperti eritrosit, trombosit dan hemoglobin (Asif, M. dkk 2013).

Perokok tidak hanya memiliki peningkatan jumlah leukosit, tetapi juga peningkatan jumlah neutrofil, limfosit, dan monosit dibandingkan dengan yang tidak terpapar asap roko. Untuk mewujudkan tujuan utama demi terjaminnya kesehatan manusia maka upaya yang harus dilakukan adalah berusaha untuk mencegah atau melakukan pengobatan penyakit yang disebabkan oleh asap rokok. Adapun upaya untuk memperkecil resiko kerusakan pada sel akibat radikal bebas salah satunya adalah dengan cara mengkonsumsi Calcitriol (Anto et al., 2002).

Hampir seluruh organ manusia yang terpapar asap rokok mengalami gangguan fungsi yang bermakna. Misalnya paru-paru akan mengalami degradasi fungsi paru, gangguan fungsi jantung, gangguan fungsi pankreas, bahkan dapat menurunkan kemampuan organ reproduksi berupa impotensi. Rokok mengandung bermacammacam zat beracun yang dapat menganggu kesehatan tubuh dan bahkan bisa 
mengakibatkan kematian (Yulianto, E.A., 2015)

Defisiensi dan insufisiensi pada Calcitriol memiliki implikasi terhadap sistem kesehatan manusia. Selama ini diketahui bahwa Calcitriol terutama berperan pada metabolisme kalsium di tulang, sehingga defisiensi Calcitriol dapat menyebabkan penyakit ricketsia. Tidak hanya itu, melainkan sejak era pre-antibiotik, minyak ikan yang merupakan sumber Calcitriol, sering dipakai pada pasien yang menderita Penyakit Paru Obstruksi Kronik (PPOK) tahap inflamasi, Tuberkulosis (TB) dan rickettsia (Herlina, I. dkk 2017).

Sampai saat ini belum banyak penelitian di Indonesia menggunakan Calcitriol untuk melihat pengaruhnya terhadap kadar limfosit pada tikus yang dipapar oleh asap rokok. Tujuan penelitian ini adalah mengetahui pengaruh pemberian Calcitriol terhadap kadar limfosit pada tikus putih (Rattus norvegicus) Galur Wistar jantan yang dipapar asap rokok. Penelitian ini diharapkan dapat digunakan sebagai bahan pengetahuan preventif untuk mengetahui dosis efektif Calcitriol yang digunakan jika diaplikasikan kepada hewan coba kelas mamalia yang ditinjau dari perlakuan uji coba laboratorium.

\section{METODE}

Jenis penelitian yang digunakan adalah eksperimental murni (true-experiment) dengan menggunakan rancangan penelitian pre and posttest with control group design untuk pemeriksaan kadar limfosit pada tikus (Rattus norvegicus) galur Wistar jantan. Penelitian ini dilakukan pada April 2020. Pemeliharaan dan pemberian perlakuan pada tikus dilakukan di Laboratorium Mikrobiologi Fakultas Kedokteran Universitas Malahayati Bandar Lampung, sedangkan untuk pemeriksaan kadar limfosit dilakukan di Laboratorium Rumah Sakit Pertamina Bintang Amin Bandar Lampung.

Subjek yang digunakan dalam penelitian ini adalah tikus putih (Rattus norvegicus) galur Wistar jantan berumur 1012 minggu dengan memiliki berat badan 150200 gram (Bachmid et al, 2015). Tikus putih (Rattus norvegicus) galur Wistar termasuk dalam hewan mamalia oleh sebab itu dampaknya terhadap suatu perlakuan mungkin tidak akan jauh berbeda dengan mamalia lainnya (Larasaty, 2013). Sampel yang digunakan dalam penelitian ini adalah tikus putih (Rattus norvegicus) galur Wistar jantan.

Tikus sebanyak 24 ekor dibagi dalam 6 kelompok secara random, yaitu kelompok kontrol 1, kelompok kontrol 2 kelompok kontrol placebo perlakuan 1, perlakuan 2 dan perlakuan 3. Kelompok kontrol 1 yaitu tikus yang tidak terpapar asap rokok dan tidak diberi Calcitriol. Kelompok kontrol 2 yaitu tikus yang dipapar asap rokok dan tidak diberi Calcitriol. Kelompok kontrol placebo yaitu tikus yang dipapar asap rokok dan diberi minyak zaitun 1ml/ekor. Kelompok perlakuan 1 yaitu tikus yang dipapar asap 
rokok dan diberi Calcitriol dengan dosis 0,25 $\mu \mathrm{gr} /$ ekor. Kelompok perlakuan 2 yaitu tikus yang dipapar asap rokok dan diberi Calcitriol dengan dosis 0,5 $\mu \mathrm{gr} /$ ekor. Kelompok perlakuan 3 yaitu tikus yang dipapar asap rokok dan diberi Calcitriol dengan dosis 1 $\mu \mathrm{gr} / \mathrm{ekor}$.

Variabel independen pada penelitian ini adalah pemaparan oleh asap rokok dan pemberian Calcitriol pada tikus putih (Rattus norvegicus) galur Wistar jantan selama 21 hari. (Leberl et al., 2013). Variabel dependen pada penelitian ini adalah nilai kadar limfosit (mg/dL) pada tikus putih (Rattus norvegicus) galur Wistar jantan. Variabel kontrol pada penelitian ini adalah berat badan tikus sebelum perlakuan, usia tikus, dan jenis kelamin tikus. Tikus didapatkan dari Pusat Budidaya Tikus Palembang (Palembang Tikus Center). Semua subjek diadaptasikan selama 7 hari dalam kandang dengan suhu ruangan \pm $25{ }^{\circ} \mathrm{C}$ dan tersedia pakan standar Comfeed BR-2 sebanyak 100g/kelompok/hari dan air minum.

Pemaparan asap rokok dilakukan pada pukul 14.00 WIB, dipapar rokok sebanyak 2 batang/hari selama 21 hari pada masingmasing kelompok (Leberl et al., 2013). Pemaparan asap rokok dilakukan dalam kandang pengasapan (smoking chamber). Alat ini dirancang khusus untuk penelitian ini. Diadaptasi dari penelitian Dewi (2016), smoking chamber terbuat dari kayu dengan ukuran $42 \mathrm{~cm} \times 29 \mathrm{~cm} \times 33 \mathrm{~cm}$ yang dilengkapi tempat pembakaran rokok, jeruji pembatas antar hewan oleh pembatas kawat dengan rokok diletakan ditempat pembakaran dalam kondisi ujung rokok yang terbakar dan ventilasi diubah menjadi menggunakan kaca agar terlihat pergerakan tikus didalamnya dan ukuran diperluas menjadi $60 \mathrm{~cm} \times 40 \mathrm{~cm} \times 40 \mathrm{~cm}$ agar semua sampel dapat dipapar bersamaan dan mendapatkan jumlah paparan yang sama. Tiap kelompok dibedakan dengan menggunakan spidol berbeda warna sebagai tanda di bagian ekor.

Pemberian Calcitriol dilakukan 2 jam setelah pemaparan asap rokok, setiap hari selama 21 hari (Leberl et al., 2013). Dosis Calcitriol yang diberikan adalah 0,25, 0,5, 1 $\mu \mathrm{gr} /$ ekor secara oral. Pemberian Calcitriol secara oral dilakukan dengan menggunakan spuit 1 cc yang disambung dengan sonde. Calcitriol diencerkan menggunakan minyak zaitun. Calcitriol digunakan karena merupakan antioksidan alami (Ladas dkk., 2004).

Tikus diinjeksi ketamin dengan dosis 0,2 cc/100 grBB secara intramuskular (IM) sebagai anastesi (Darmalaksana dkk., 2018). Darah diambil dari sinus orbitalis menggunakan mikrohematokrit yang dimasukan melalui pangkal sudut bola mata sambil diputar halus ke arah belakang bola mata hingga darah mengalir melalui mikrohematokrit tersebut. Darah kemudian di tampung sebanyak $1 \mathrm{ml}$ secara hati-hati ke dalam tabung hampa udara (vacutainer tube) yang berisi antikoagulan 
ethylenediaminetetraacetic acid (EDTA) (Mohri et al., 2007).

Pada sampel darah yang sudah diambil kemudian dihomogenkan dengan menggunakan multifunctional mixer selama 5 menit. Untuk menghitung kadar limfosit yang terdapat dalam darah tikus Wistar diukur menggunakan auto hematology analyzer. Kadar normal limfosit pada tikus putih adalah 68 - 84 \% (Dewi, 2016).

Analisis data yang telah diperoleh dilakukan dengan pengecekan kelengkapan data dan melakukan entry data ke dalam software SPSS. Selanjutnya mengecek frekuensi distribusi, uji normalitas menggunakan Shapiro wilk karena pada sampel penelitian yang diambil < 50 sampel. Selanjutnya dilakukan uji paired $T$ - test terhadap kadar limfosit untuk menganalisis perbedaan nilai sebelum dan sesudah diberikannya perlakuan karena data terdistribusi normal. Kemudian dilakukan analisis data untuk mengetahui perbedaan antar kelompok perlakuan pada limfosit dengan menggunakan uji komparatif one-way ANOVA karena data berdistribusi normal. selanjutnya dilakukan uji statistik post hoc LSD dilakukan pada kadar limfosit untuk menganalisis perbedaan rerata antar kelompok, sehingga dapat diketahui kelompok yang berpengaruh pada perbedaannya (Notoatmodjo, 2012)

\section{HASIL DAN PEMBAHASAN}

Hasil karakteristik sampel menggunakan 24 ekor tikus putih (Rattus norvegicus) galur Wistar jantan berusia 10-12 minggu, bulu berwarna putih bersih, dengan keadaan umum sehat, dapat bergerak aktif, dan tidak terdapat luka pada tikus putih (Rattus norvegicus) galur Wistar jantan.

Sebelum perlakuan batas berat badan tikus putih (Rattus norvegicus) galur Wistar jantan sesuai dengan kriteria inklusi yaitu 150-200gram dengan nilai rerata berat badan tikus sebelum perlakuan pada kelompok K1 (175,00 \pm SD 19.149), kelompok K2 (170,00 \pm SD 25.82), kelompok K3 (177,50 \pm SD 5,00), Kelompok P1 (187,50 \pm SD 18.93), Kelompok P2 (180,00 \pm SD 16.33), dan Kelompok P3 (190,00 \pm SD 14.142). Kemudian setelah perlakuan terjadi perubahan berat badannya pada setiap kelompok yaitu pada kelompok K1 $(187,50 \pm$ SD 15.00), kelompok K2 $(180,00 \pm$ SD 18.257), kelompok K3 (195,00 \pm SD 5,774), Kelompok P1 $(205,00 \pm$ SD 17.321), Kelompok P2 (200,00 \pm SD 14.142), dan Kelompok P3 (212,50 \pm SD 17.078).

Hasil pengukuran kadar limfost dinyatakan dalam satuan $\mathrm{mg} / \mathrm{dl}$ dan dilakukan pemeriksaan uji laboratorium menggunakan alat auto hematology analyzer. Sebelum dilakukan pemerriksaan, darah dihomogenkan dengan menggunakan multifunctional mixer selama 5 menit dengan tujuan agar sampel darah yang diambil tidak adanya penggumpalan atau komponen darah masih tetap dalam keadaan tercampur rata. Darah tikus diambil sebanyak 2 kali yaitu sebelum tikus dipapar asap rokok dan diberi 
Calcitriol, dan setelah tikus dipapar asap rokok dan diberi Calcitriol selama 21 hari.

Nilai perbedaan rerata limfosit sebelum dan sesudah diberi perlakuan dapat dilihat pada Tabel 2 data dianalisis menggunakan program SPSS. Hasil Laboratorium sebelum dilakukannya perlakuan pada tikus putih menunjukan hasil dalam batas normal

Tabel 1. Profil dan diferensiasi leukosit tikus putih menurut literatur

\begin{tabular}{lll}
\hline Total Leukosit & $7,30-12,66 \times 10^{3} \mathrm{sel} / \mu \mathrm{L}^{*}$ \\
\hline Diferensiasi leukosit & Nilai relatif $(\%)^{* *}$ & Nilai absolut $\left(\times 10^{3} \mathrm{sel} / \mu \mathrm{L}\right)^{* * *}$ \\
\hline Neutrofil & $9,00-34.00$ & $1,25-3,71$ \\
Limfosit & $65-84$ & $5,07-9,07$ \\
Monosit & $0-5$ & $0,05-0,44$ \\
Eosinofil & $0-6$ & $0,04-0,30$ \\
Basofil & $0-1,5$ & $0,00-0,03$ \\
\hline
\end{tabular}

Sumber : * Smith dan Mangkoedidjojo 1988, ${ }^{* *}$ Baker et al. 1980, ${ }^{* * *}$ Thrall et al. 2004

Berdasarkan tabel profil dan limfosit menunjukkan perbedaan yang diferensiasi leukosit tikus putih menurut bermakna $(\mathrm{p}<0,05)$ pada kelompok K2 $(\mathrm{p}=$ literatur kadar normal limfosit tikus putih 0,014), kelompok K3 ( $p=0,049)$, kelompok yaitu $65.00-84.00 \%$ P1 $(p=0,012)$ dan kelompok P3 $(0,001)$.

Hasil uji normalitas menunjukkan rasio limfosit sebelum dan sesudah diberi perlakukan berdistribusi normal $(\mathrm{P}>0,05)$ Sedangkan kelompok K1 ( $\mathrm{p}=0,115)$ dan kelompok P2 $(\mathrm{p}=0,066)$. Tidak terdapat perbedaan secara statistik.

pada semua kelompok. Uji Paired t-test kadar

Tabel 2. Perbedaan nilai rerata \pm SD kadar limfosit sebelum dan setelah diberi perlakuan

\begin{tabular}{|c|c|c|c|}
\hline Kelompok & $\begin{array}{c}\text { Kadar Limfosit } \\
\text { Sebelum perlakuan }\end{array}$ & $\begin{array}{c}\text { Kadar Limfosit } \\
\text { Sesudah } \\
\text { perlakuan }\end{array}$ & $\begin{array}{lr}\text { Nilai } p & \text { uji } \\
\text { paired } & \text { T-Test } \\
\text { Limfosit } & \end{array}$ \\
\hline & Mean \pm SD & Mean \pm SD & \\
\hline Kontrol & $71,75 \pm 2,363$ & $75,50 \pm 3,873$ & 0,115 \\
\hline Asap & $73,50 \pm 1,291$ & $76,50 \pm 1,291$ & 0,014 \\
\hline Asap-placebo & $75,75 \pm 2,630$ & $73,00 \pm 2,944$ & 0,049 \\
\hline Asap-Calcitriol 0,25 $\mu \mathrm{gr}$ & $75,75 \pm 2,217$ & $72,25 \pm 1,893$ & 0,012 \\
\hline Asap-Calcitrool 0,5 $\mu \mathrm{gr}$ & $76,25 \pm 4,500$ & $72,25 \pm 2,062$ & 0,066 \\
\hline Asap-Calcitriol $1 \mu \mathrm{gr}$ & $79,00 \pm 1,414$ & $71,00 \pm 1,414$ & 0,001 \\
\hline
\end{tabular}


Tabel 3. Rerata \pm kadar Limfosit sebelum dan setelah perlakuan dengan analisis post hoc LSD (*) terdapat perbedaan yang bermakna $(p<0,05)$

\begin{tabular}{|c|c|c|c|c|}
\hline Kelompok & Kelompok & $\begin{array}{c}\text { Mean } \\
\text { difference }\end{array}$ & Std.Eror & Sig. \\
\hline \multirow{5}{*}{ Kontrol } & Asap & -1.000 & 1.712 & 0,566 \\
\hline & Asap-placebo & 2.500 & 1.712 & 0,161 \\
\hline & Asap-Calcitriol 0,25 $\mu \mathrm{gr}$ & 3.250 & 1.712 & 0,074 \\
\hline & Asap-Calcitrool 0,5 $\mu \mathrm{gr}$ & 3.250 & 1.712 & 0,074 \\
\hline & Asap-Calcitriol $1 \mu \mathrm{gr} *$ & 4.500 & 1.712 & 0,017 \\
\hline \multirow{5}{*}{ Asap } & Kontrol & 1.000 & 1.712 & 0,566 \\
\hline & Asap-placebo & 3.500 & 1.712 & 0,056 \\
\hline & Asap-Calcitriol 0,25 $\mu \mathrm{gr} *$ & 4.250 & 1.712 & 0,023 \\
\hline & Asap-Calcitrool 0,5 $\mu \mathrm{gr} *$ & 4.250 & 1.712 & 0,023 \\
\hline & Asap-Calcitriol $1 \mu \mathrm{gr} *$ & 5.500 & 1.712 & 0,005 \\
\hline \multirow{5}{*}{$\begin{array}{l}\text { Asap- } \\
\text { placebo }\end{array}$} & Kontrol & -2.500 & 1.712 & 0,161 \\
\hline & Asap & -3.500 & 1.712 & 0,056 \\
\hline & Asap-Calcitriol 0,25 $\mu \mathrm{gr}$ & .750 & 1.712 & 0,667 \\
\hline & Asap-Calcitrool 0,5 $\mu \mathrm{gr}$ & .750 & 1.712 & 0,667 \\
\hline & Asap-Calcitriol $1 \mu \mathrm{gr}$ & 2.000 & 1.712 & 0,258 \\
\hline \multirow{5}{*}{$\begin{array}{c}\text { Asap- } \\
\text { Calcitriol } \\
0,25 \mu g r\end{array}$} & Kontrol & -3.250 & 1.712 & 0,074 \\
\hline & Asap* & -4.250 & 1.712 & 0,023 \\
\hline & Asap-placebo & -.750 & 1.712 & 0,667 \\
\hline & Asap-Calcitrool 0,5 $\mu \mathrm{gr}$ & .000 & 1.712 & 1.000 \\
\hline & Asap-Calcitriol $1 \mu \mathrm{gr}$ & 1.250 & 1.712 & 0,475 \\
\hline \multirow{5}{*}{$\begin{array}{l}\text { Asap- } \\
\text { Calcitriol 0,5 } \\
\mu g r\end{array}$} & Kontrol & -3.250 & 1.712 & 0,074 \\
\hline & Asap* & -4.250 & 1.712 & 0,023 \\
\hline & Asap-placebo & -.750 & 1.712 & 0,667 \\
\hline & Asap-Calcitriol 0,25 $\mu \mathrm{gr}$ & .000 & 1.712 & 1.000 \\
\hline & Asap-Calcitriol $1 \mu \mathrm{gr}$ & 1.250 & 1.712 & 0,475 \\
\hline \multirow{5}{*}{$\begin{array}{l}\text { Asap- } \\
\text { Calcitriol } 1 \\
\mu g r\end{array}$} & Kontrol * & -4.500 & 1.712 & 0,017 \\
\hline & Asap* & -5.500 & 1.712 & 0,005 \\
\hline & Asap-placebo & -2.000 & 1.712 & 0,258 \\
\hline & Asap-Calcitriol 0,25 $\mu \mathrm{gr}$ & -1.250 & 1.712 & 0,475 \\
\hline & Asap-Calcitriol 0,5 $\mu \mathrm{gr}$ & -1.250 & 1.712 & 0,475 \\
\hline
\end{tabular}

Keterangan: *) berbeda signifikan

Analisis statistik post hoc LSD (Tabel 3) K2 dengan Kelompok P1 (p= 0,023), menunjukkan adanya perbedaan yang Kelompok K2 dengan Kelompok P2 (p= bermakna $(p<0,05)$ antara kelompok K1 0,023), Kelompok K2 dengan Kelompok P3 dengan Kelompok P3 $(p=0,017)$, Kelompok $\quad(p=0,005)$, Kelompok P1 dengan Kelompok 
K2 ( $p=0,023)$, dan Kelompok P2 dengan Kelompok K2 (p= 0,023), Kelompok P3 dengan Kelompok K1 $(p=0,017)$ serta Kelompok P3 dengan Kelompok K2 ( $p=$ $0,005)$.

Hasil uji statistik diperoleh nilai $p$ value 0,000 , berarti pada alpha $5 \%$ dapat disimpulkan terdapat pemberian Calcitriol terhadap kadar limfosit pada tikus (Rattus norvegicus) galur Wistar jantan yang dipapar asap rokok. Adanya kenaikan kadar limfosit Pada Kelompok K1 (Kelompok Kontrol) kemungkinan disebabkan oleh pertambahan aliran leukosit dari sumsum tulang ke sirkulasi. Pergerakan leukosit dari MGP ke CGP dan aliran leukosit dari sirkulasi ke jaringan. Aliran leukosit ke sumsumm tulang dapat meningkat pada keadaan stres. Hal ini dapat dijelaskan bahwa pada stres terdapat peningkatan glukokortokoid sampai 20 kali lipat, sedangkan pemberian dosis tunggal dengan masa kerja singkat meningkatkan aliran dari sumsum tulang ke dalam darah. Seperti telah diketahui stok leukosit pada sumsum tulang sebanyak 15 sampai 20 kali jumlah keseluruhan leukosit yang ada dalam sirkulasi (Katzung, 2002).

Penyebab lain limfosit naik dikarenakan faktor suhu ruangan yang tidak stabil sehingga tikus mengalami stress. Penelitian lain mengatakan bahwa pada saat terjadi stres, saraf simpatik dan kelenjar adrenal akan mempengaruhi sistem imun, yaitu jaringan limfoid, termasuk thymus, limfe, dan kelenjar getah bening. Senyawa endogen yang dilepaskan selama stress dapat meningkatkan atau menekan fungsi sistem imun. Sistem imun melibatkan berbagai jenis sel dengan fungsi saling terkait (Huether, S.E., McCance, K.L. 2004)

Adanya kenaikan kadar limfosit namun masih dalam batas normal pada kelompok K2 (dipapar asap rokok saja ) disebabkan karena waktu penelitian singkat dan kurangnya dosis rokok yang diberikan sehingga pada kelompok K2 tikus tidak terinfeksi atau tidak mengalami inflamasi. Pada penelitian (Rusmini, H. dkk 2019) terbukti adanya penurunan kadar hemoglobin pada darah tikus yang dipapar asap rokok lalu diberi vitamin D dengan dosis 8 batang rokok selama 30 menit perhari dengan lamanya perlakuan 14 hari. Dalam penelitian ini menunjukan adanya pengaruh dosis rokok yang diberikan setiap harinya.

Hal ini tidak terjadi pada hewan saja, akan tetapi adanya penelitian dari Department of Biology, College of Science, Salahaddin University Iraq terhadap perokok usia 25-35 dan 36-45 tahun yang merokok minimal 10 batang selama 10 tahun di kota Erbil menunjukkan bahwa terdapat peningkatan kadar leukosit total, neutrofil, eosinofil, monosit, dan limfosit pada kedua kelompok usia namun untuk basofil tidak terdapat peningkatan bermakna (Aula et al 2012).

Adanya penurunan kadar limfosit pada kelompok K3 (dipapar asap rokok dan diberi minyak zaitun), kemungkinan disebabkan 
dari minyak zaitun yang memiliki manfaat antara lain sebagai sumber kaya antioksidan, dan dapat meningkatkan sirkulasi. Flavonoid yang terkandung dalam minyak zaitun merupakan senyawa fenolik yang berperan sebagai anti inflamasi dengan kemampuan menghambat pelepasan mediator kimiawi, sintesis sitokin, Th2 (1L-4 dan 1L-13), dan ekspresi ligan CD40 melalui afinitasnya yang tinggi terhadap sel mast dan basophil sebagai pengekspresi reseptor Ig E. Beberapa studi yang membuktikan manfaat Zaitun terhadap asma melalui kandungan flavonoid yang dapat menghambat pelepasan mediator inflamasi (Tanaka \& Takahashi, 2013)

Adanya penurunan kadar limfosit namun masih dalam batas normal pada kelompok P1 (dipapar asap rokok dan diberi Calcitriol 0,25 $\mu \mathrm{gr} /$ ekor), terjadi karena Calcitriol dapat meningkatkan kekebalan dengan modulasi sitokin TGF- $\beta$ dan IL-10 Dalam sel T, Calcitriol menurunkan sel dendritik OX40L dan meningkatkan pengaturan TGF- $\beta$. Hal ini menyebabkan peningkatan TGF- $\beta$-positif dan menurunkan tingkat sitokin Th2 (Brehm et al., 2008).

Adanya penurunan kadar limfosit masih dalam batas normal pada kelompok P2 (dipapar asap rokok dan diberi Calcitriol 0,5 $\mu g r$ / ekor), kemungkinan disebabkan Calcitriol merupakan antioksidan yang dapat membersihkan radikal bebas akibat asap rokok dan mencegah radikal bebas merusak sel. Antioksidan memiliki efek protektif dengan menetralkan radikal bebas yang bersifat toksik dengan memproduksi metabolisme sel alami (Sen et al., 2010). Pada kelompok ini hasil laboratorium menunjukan hampir sama nilai kadar limfosit dengan kelompok yang diberikan dosis 0,25 $\mu \mathrm{gr}$ karena hewan coba pada kelompok yang diberikan dosis 0,5 $\mu$ gr pada saat pemberian pakan, sisa pakannya masih terdapat sisa, sedangkan kelompok perlakuan Calcitriol 0,25 $\mu$ gr tidak terdapat sisa makanan pada saat dilakukan pemberian makan dihari berikutnya. Setiap kelompok diberikan pakan yang sama yaitu pakan standar Comfeed BR-2 sebanyak 100g/kelompok/hari dan air minum. Penurunan jumlah sel darah putih juga dapat menjadi indikator adanya penurunan imunitas tubuh. Hal ini menunjukan sebagian besar mekanisme imunitas tubuh tergantung pada replikasi sel, sintesis sel dan produksi komponen protein aktif yang sangat dipengaruhi dari asupan makanan (Anggraeny, Olivia, et al., 2016).

Adanya penurunan kadar limfosit pada kelompok P3 (dipapar asap rokok dan diberi Calcitriol $1 \mu \mathrm{gr} /$ ekor), kemungkinan disebabkan oleh Calcitriol mempunyai peran positif baik pada imunitas non spe-sifik maupun spesifik dan dapat memodulasi, baik sistem kekebalan tubuh alami ataupun yang didapat. Adanya kemampuan untuk menekan terjadinya proliferasi sel $\mathrm{T}$ dengan hasil akhir terjadinya penurunan produksi cytokines inflamasi atau yang biasa disebut dengan interleukin (Hermawan, D. 2016) 
Fungsi utama Calcitriol adalah membantu pembentukan dan pemeliharaan tulang bersama vitamin A dan vitamin C, hormon-hormon paratiroid dan kalsitonin, protein kolagen, serta mineral-mineral kalsium, fosfor, magnesium dan flour. Fungsi khusus Calcitriol dalam hal ini adalah membantu pengerasan tulang dengan cara mengatur agar kalsium dan fosfor tersedia didalam darah untuk diendapkan pada proses pengerasan tulang (Almatsier, 2010).

Dalam saluran cerna, Calcitriol meningkatkan absorpsi dengan cara merangsang sintesis protein pengikatkalsium dan protein pengikat fosfor pada mukosa usus halus. Didalam tulang, Calcitriol bersama hormon paratiroid merangsang pelepasan kalsium dari permukaan tulang ke dalam darah. Dalam ginjal, Calcitriol merangsang reabsorbsi kalsium dan fosfor (Almatsier, 2010).

Calcitriol mempunyai peran yang sangat luas dalam tubuh, tidak hanya mengatur homeostasis kalsium dan fosfat untuk kesehatan tulang dan gigi, Calcitriol juga memainkan peran penting dalam proliferasi dan diferensiasi sel, sistem imunitas, sistem syaraf, melindungi fungsi syaraf, mengurangi stress oksidatif, sebagai antiinflamasi, antimikroba dan anti kanker (Gil et al., 2018 dan Michael et al., 2018).

Calcitriol sebagai sistem endokrin adalah komponen penting dalam interaksi antara ginjal, tulang, hormon paratiroid, dan usus yang hasilnya menjaga kadar kalsium ekstrak seluler dalam batas normal sehingga dapat berguna dalam proses fisiologi dan integritas skeletal (Dusso et al., 2005 dan Akizawa et al., 2003).

\section{KESIMPULAN}

Berdasarkan hasil penelitian yang berjudul Pengaruh Pemberian Calcitriol Terhadap Kadar Limfosit Pada Tikus Putih (Rattus Norvegicus) Galur Wistar Jantan Yang Dipapar Asap Rokok disimpulkan bahwa secara teori Calcitriol dapat menurunkan kadar limfosit. Dalam penelitian ini membuktikan adanya penurunan kadar limfosit masih dalam batas normal setelah diberikan perlakuan, karena keterbatasan waktu penelitian sehingga membuat hewan coba tidak terinfeksi paparan asap rokok dan tidak mencapai tahap inflamasi.

Dosis efektif Calcitriol yang digunakan untuk menstabilkan limfosit dalam penelitian ini adalah dengan menggunakan dosis $1 \mu \mathrm{g} /$ ekor.

\section{DAFTAR PUSTAKA}

Akizawa, T., Kazuhiro, S., Hatamura, I., Kamimura, M., Mizobuchi, M., Narukawa, N. 2003. New strategies for treatment of secondary hyperparathyroidism. 41 (3):100-103.

Almatsier, S. 2010. Prinsip Dasar Ilmu Gizi. Gramedia Pustaka Utama, Jakarta.

Anggraeny, O., Dianovita, C., Putri, E. N., Sastrina, M., \& Dewi, R. S. (2016). Korelasi Pemberian Diet Rendah Protein Terhadap Status Protein, Imunitas, Hemoglobin, dan Nafsu Makan Tikus Wistar Jantan (The 
Correlation of Low Protein Diet Administration on Status of Protein, Immunity, Hemoglobin, and Appetite of Male Wistar Rats Rattus norvegicus). Indonesian Journal of Human Nutrition, $3(2), 105-122$.

Anto, R.j., Mukhopadhyay, A., Dening, K., Aggrawal, BB. 2002. Curcumin (diferuloyl - methane) Induces apoptosis through avtivation of caspase -8, BID cleavage and cyto chrome $c$ realase. 23:143 - 150.

Asif, M., Karim, S., Umar, Z., Malik, A., Ismail, T., Chaudhary, A., Hussain, A. M., Rasool, M. 2013. Effect of cigarette smoking based on hematological parameters comparison between male smokers and non-smokers. Turkish Journal of Biochemistry/Turk Biyokimya Dergisi. Jan 1;38(1)

Aula, F.A., Qadir, F.A. 2012. Effect of cigarettesmoking on some immunological and hematological parameters in male smokers in Erbil City. Jordan Journal of Biological Science.6(2):159-66.

Bachmid, N. 2015. Uji aktivitas antikolesterol ekstrak etanol daun patikan emas (Euphorbia prunifolia Jacq.) pada Tikus Wistar yang hiperkolesterolemia. Jurnal MIPA. 4(1): 29-35.Balitbangkes RI. 2012. Global Adult Tobacco Survey: Indonesia report.

Baker HJ, Lindsey JR \& Weishbroth SH. The Laboratory Rat, Volume 1, New York (US), Academic Press. 1980; hh. 153155.

Brehm, J.M., Perez, A.E., Klei, L., Roeder, K., Barmada, M., Boutaoui, N., Forno, E., Kelly, R., Paul, K.m Sylvia, J., and Litonjua, A.A., 2012. Vitamin D insufficiency and severe asthma exacerbations in Puerto Rican Children. American Journal of respiratory and Critical care Medicine, 186 (2);140-146.

Darmalaksana, I.G.N., Sudimantini, L.M., Jayawarditha, A.A.G. dan Dada, I.K.A.
2018. Gerusan Daun Pegagan Mempercepat Kesembuhan Luka Bakar pada Tikus Putih. Buletin Veteriner Udayana. 2018;137-146.

Dewi, F.K. 2016 . Efek Ekstrak Kulit Buah Rambutan Terhadap Jumlah Eritrosit, Kadar hemoglobin, dan Hematokrit Tikus Putih yang Dipapar Asap Rokok.

Duso, A.D., Brown, A.J., Slatopolsky, E. 2005. Vitamin D. Am. J Physiol. Renal. Physiol. 289: 8-28.

Gil, A., Plaza, D.J., Mesa, M.D. 2018. Vitamin D Classic and novel actions. 72: 87-95.

Herlina, I., Purwanto, B., \& Sugiarto, S. 2017. Pengaruh Pemberian 1, 25 Dihydroxyvitamin D (Calcitriol) Terhadap Kadar Fibroblast Growth Factor 23 Dan Albuminuria Pada Pasien Penyakit Ginjal Kronik Stadium V Yang Menjalani Hemodialisis. Biomedika, 9(1).

Hermawan, D. 2016. Sehat Selalu dengan Vitamin D. Penerbit Andi.

Huether, S.E., McCance, K.L. 2004. Understanding pathophysiology. 222300.

Katzung, B.G. 2002. Basic and clinica Pharmacology.

Kementrian Kesehatan Republik Indonesia. 2010. Riset kesehatan dasar (Riskesdas). Badan Penelitian dan Pengembangan Kesehatan, Jakarta.

Ladas, E.J., Jacobson, J.S., Kennedy, D.D., Teel, K., Fleischauer, A., dkk. 2004. Antioxidants and cancer therapy a systematic review. Journal of clinical oncology. 22(3): 517-528.

Larasati, W. 2013. Uji Antifertilitas Ekstrak Etil Asetat Biji Jarak Pagar Uatropha curas L.) pada tikus putih jantan (Rattus Norvegicus) Galur Sprague Dawley secara In Vivo. UIN Syarif Hidayatullah, Jakarta.

Leberl, M., Kratzer, A., \& Taraseviciene, S.L. 2013. Tobacco smoke induced 
COPD/emphysema in the animal model-are we all on the Frontiers in physiology. 2013, (4)91

Mohri, M.K., Sharifi., Eidi, S. 2007. Hematology and serum biochemistri of Holstein dairy calves, Age related changes and comparison with blood composition in adults, Veterinary science. 83: 30 - 39.

Notoatmojo, S. 2012. Metodologi Penelitian Kesehatan. Rineka Cipta, Jakarta.

Rusmini, H., Fitriani, D., Hermawan, D., \& Emilda, D. A. 2019. Pengaruh Vitamin D3 Terhadap Kadar Hemoglobin Tikus Wistar yang Dipapar Asap Rokok. Jurnal Ilmu Kesehatan, 1(1), 22-28.

Sen, S., Chakraborty, R., Sridhar, C., Reddy, Y.S.R., and De, B. 2010. Free radicals, antioxidants, diseases and phytomedicines, current status and future prospect. International journal of pharmaceutical sciences review and research. 3(1): 91-100.

Smith JB, Mangkoewidjojo S. Pemeliharaan, Pembiakan, Penggunaan Hewan Percobaan di Daerah Tropis. UI Press, Jakarta. 1998.

Tanaka, T., \& Takahashi, R. 2013. Flavonoids and asthma, Nutrients.5(6): 21282143.

Thrall, M.A., Baker, D.C., Campbell, T.W., Denicola, D., Fettman, M.J., Lassen, E.D., Rebar, A., Weiser, G. 2004. Veterinary Hematology and Clinical Chemistry. 106107.

World Health Organization. 2015. WHO global report on trends in prevalence of tobacco smoking.

Yulianto, E.A. 2015. Persepsi Siswa Smk Kristen (Ti) Salatiga Tentang Bahaya Merokok Bagi Kesehatan. J Phys Educ.4(5);1807-13. 